\title{
Marek Kaźmierczak \\ O atrofii kultury literackiej. Uwagi na przykładzie semiotycznych i rzeczowych funkcji książek w filmie Sara
}

\begin{abstract}
Kaźmierczak Marek, O atrofii kultury literackiej. Uwagi na przykładzie semiotycznych i rzeczowych funkcji książek w filmie Sara [Atrophy of Literature. Remarks about the Semiotic Functions of Books in the Film Sara]. „Przestrzenie Teorii” 32. Poznań 2019, Adam Mickiewicz University Press, pp. 383-400. ISSN 1644-6763. DOI 10.14746/pt.2019.32.21.

The article concerns the relations between the main character of the film Sara (directed by M. Ślesicki in 1997) and books (especially Dostoyevsky's Crime and Punishment) in the context of social and political changes in Poland in the 1990s. The presence of books in popular Polish films from that period is not described in research, hence this article provides a short introduction to this subject. The main hypothesis of the paper is that the presence of books on the margins of narration in popular films reflects social changes in thinking about literature.
\end{abstract}

KEYWORDS: book, film, sign, semiotics, culture

\section{Wprowadzenie}

Film Sara (1997) był następnym po filmie Tata dziełem Macieja Ślesickiego. W rozmowie z Jakubem Gierałtem, na pytanie o to, czy jest coś, co łączy te obrazy, reżyser filmów stwierdził: „Owszem, to taki Tato, tylko dla bardzo dorosłych widzów. Podobnie jak w poprzednim filmie pomieszaliśmy gatunki i film jest czasem śmieszny, a czasem brutalny. Zrobiłem Sarę trochę na przekór"1. W badaniach film Sara zaliczany jest do tzw. nurtu kina bandyckiego, wprowadzającego modę na określony „gatunek [...], sytuacje fabularne, świat przedstawiony, język i postaci”", kina, które od początku było traktowane jako „oznaka nowych czasów”3. Wśród filmów zaliczanych do tego nurtu za najbardziej reprezentatywny uznaje się Psy w reż. Władysława Pasikowskiego (1992).

${ }^{1}$ Por. Jeszcze nie raz was zaskoczę. Rozmowa z Maciejem Ślesickim, rozm. J. Gierałt, „Kino” 1997, nr 5, s. 14.

2 Tamże.

${ }^{3}$ M. Przylipiak, J. Szyłak, Kino najnowsze, Kraków 1999, s. 179. Por. M. Adamczak, Globalne Hollywood, filmowa Europa i polskie kino po 1989 roku. Przeobrażenia kultury audiowizualnej przełomu stuleci, Gdańsk 2010, s. 279-280. 
Proponuję, aby w toku dociekań odnieść się nie tyle do gatunkowej i stylistycznej konwencji, ale do tematu potraktowanego marginalnie w dziele, choć w moim przekonaniu ważnego, bo odzwierciedlającego zjawisko kulturowe, które nazywam atrofią kultury literackiej. Obraz polskiej rzeczywistości przedstawiany w filmach zaliczanych do nurtu bandyckiego, ale też $\mathrm{w}$ wybranych komediach sensacyjnych, zdeterminowany jest przez postaci, dla których kultura literacka najczęściej okazuje się balastem w ich dążeniach do sukcesu finansowego i politycznego. Filmowe obrazy książki, literatury, intelektualisty służą sportretowaniu konsekwencji przemian społeczno-ekonomiczno-politycznych, obnażając przy tym karykaturalność postaw i powierzchowność relacji międzyludzkich.

Obrazy „migracji” kulturowego centrum prezentowane w filmach gangsterskich z tego okresu, wszak o kulturze decydują ci „biznesmeni”, których, jak w przypadku filmu Chtopaki nie płacza w reż. Olafa Lubaszenki (2000), stać na jej finansowanie, powoduje redefinicję tradycyjnego, kanonicznego wzorca kultury. To, co peryferyjne - staje się porządkiem normatywnym albo przynajmniej za taki uznawanym z powodu oddziaływania mediów i cyrkulacji kapitału. W filmach zaliczanych do nurtu kina bandyckiego oraz do komedii sensacyjnych nie traktuje się literatury jako ważnego tematu, co oczywiście wynika z przyjętych konwencji gatunkowych.

W tym kontekście film Sara okazuje się ważnym przykładem obrazującym atrofię kultury literackiej w latach dziewięćdziesiątych XX wieku. Zanik, a tak rozumiem słowo atrofia, kultury literackiej przejawia się w kinie tego okresu w instrumentalnym traktowaniu książek, w banalizacji literatury, w utrwalaniu schematycznych przedstawień intelektualisty. Atrofia kultury literackiej charakteryzowana jest przez pragmatyczne nastawienie do przyswajanej wiedzy i utylitarne podejście do lektury. W miejsce beletrystyki postaci filmowe czytają poradniki o dobrym życiu czy o seksie (Sara z filmu Macieja Ślesickiego), a wiedza nabywana na skutek lektur jest produktem, który można nabyć (Stella z filmu $E=m c^{2}$ w reż. Olafa Lubaszenki [2002] „kupuje” pracę magisterska). Atrofia kultury literackiej przejawia się w redukcji różnorodności postaw i stylów odbioru, a jednocześnie w podtrzymaniu stereotypu, że człowiek książkowy dysponuje wiedzą nieprzydatną i dlatego nie może być kimś, wokół kogo ogniskują się zdarzenia, nie może modelować postaw, które mogłyby zostać uznane - jeśli nie za normatywne, to przynajmniej za alternatywne wobec tych, które prezentowane sa przez nowych polskich kapitalistów czy polityków. Atrofia kultury literackiej przejawia się w idiomatyczności praktyk kulturowych. Gdy myślimy o scenie z filmu Chtopaki nie płacza, w której pojawia się cytat z dzieła, którego reżyserem był Visconti, zatytułowanego Śmierć $w$ Wenecji (1971), to widzimy, w jak równoległych światach - idiomach kulturowych - funkcjonuja 
te osoby, dla których Visconti oraz Mann są figurami kanonu kultury, oraz te postaci (w filmie symbolizowane przez gangsterów), dla których Śmierć $w$ Wenecji to „nieudany kryminał”. Jedną z konsekwencji transformacji ustrojowej w Polsce w tamtym okresie było właśnie wyodrębnienie się równoległych kulturowo światów modelowanych przez całkowicie odmienne praktyki lekturowe i audiowizualne (lub w niektórych przypadkach ich brak). Te porządki kulturowe sa do pewnego stopnia nieprzekładalne, dlatego literatura z kulturowego centrum „migruje” na peryferia ustrojowo transformującej się Polski.

\section{Książka jako rzecz i znak}

W filmie Sara książka pojawia się jako rzecz, jako rekwizyt, jako przedmiot rozmowy. Marginalna obecność jest intrygująca z powodu sytuacji, w których książka zaczyna pełnić złożone funkcje komunikacyjne obrazujące zmiany społeczne i kulturowe. W niniejszym artykule zostanie omówiony jeden z przykładowych, niereprezentatywnych ze względu na jego recepcję, obrazów odzwierciedlających atrofię kultury literackiej. Napisałem „niereprezentatywnych”, gdyż film Sara, który będzie przedmiotem mojej analizy i interpretacji, nigdy wcześniej w badaniach nie był rozpatrywany w kontekście, o którym mowa. Nikt nie badał społecznych reakcji na ten obraz i choć był to film ongiś popularny ${ }^{4}$, to nie na tyle, żeby „skolonizować" wyobrażenia społeczne tak intensywnie, aby mówiono o nim jako o dziele przynajmniej kultowym, wręcz odwrotnie, traktowano ten obraz nieufnie, krytycznie $^{5}$.

Poniżej proponuję interpretację, w której traktuję film Sara jako metaforycznie nacechowany obraz społeczno-kulturowych przemian z drugiej połowy lat dziewięćdziesiątych XX wieku. Rezultatem tych przemian jest atrofia kultury literackiej. Zakładam, że film Macieja Ślesickiego, obok innych dzieł z tego okresu, jest tekstem kultury krytycznie odnoszącym się do okresu transformacji ustrojowej w Polsce.

W kinie z nurtu bandyckiego mowa jest o trudach wynikajaccych z rozliczania się społeczeństwa polskiego z komunistyczną przeszłością czy o for-

${ }^{4}$ Por. m.in. następujace recenzje: B. Janicka, Tato, pa! (,Sara”), „Kino” 1997, nr 7-8, s. 40-42; W. Kot, Antybohater w potrawce. Film „Sara” w reżyserii Macieja Ślesickiego, „Wprost” 1997, nr 22, s. 99; Z. Pietrasik, O kurna, Linduś!, „Polityka” 1997, nr 23, s. 54.

${ }^{5}$ Por. recenzje na temat filmu, które opublikowano m.in. w czasopismach „Wprost” (Wiesław Kot), „Polityka” (Zdzisław Pietrasik), „Kino” (Bożena Janicka), ale także: „Sara”. Bajka dla dorostych, <https://film.interia.pl/wiadomosci/news-sara-bajka-dla-doroslych,nId,2396697\#comments4-1> [dostęp: 10.08.2019]. 
mowaniu się nowych porządków: ekonomicznego, społecznego i kulturowego, w horyzoncie których przedstawiane są zjawiska wynikające z dychotomii między kulturą wysoką i niską (używając tradycyjnej dychotomii). Z jednej strony popularnością cieszą się wśród widowni następujące filmy: Psy w reż. Władysława Pasikowskiego (1992), Młode wilki w reż. Jarosława Żamojdy (1995) czy serial Ekstradycja w reż. Wojciecha Wójcika (seria pierwsza z 1995 roku, następnie kolejna seria z 1996 roku i wreszcie z 1998 roku), a z drugiej - komedie sensacyjne reżyserowane przez Olafa Lubaszenkę: Chtopaki nie płacza (2000), Poranek kojota (2001), $E=m c^{2}$ (2002). W wymienionych filmach powraca $\mathrm{w}$ różnych formach obraz atrofii kultury literackiej, a szerzej - coraz bardziej „przygodnej” obecności intelektualisty w życiu społecznym.

Film Sara jest być może ostatnim filmem, w którym płonąca książka miała coś znaczyć jako znak odnoszący się do czegoś ważnego, czego jednak obraz ruchomy nie mógł pokazać ani język bohaterów wypowiedzieć, choć należy pamiętać, że Macieja Ślesickiego interesowało w tamtym okresie tworzenie tzw. dobrego kina, dobrej opowieści, czyli przykuwającej uwagę widza. Nie zajmował się tym, na ile jego dzieło będzie się odnosiło do problemów społecznych czy kulturowych:

Po lekturze scenariusza Taty ktoś napisał: „,nareszcie pojawił się młody człowiek podejmujący ważne problemy społeczne". [...]. W obu moich filmach obchodziła mnie jedynie ciekawa historia sprawiająca, że widz wyjdzie z kina z jakimiś uczuciami. Bo wszystko można o tych filmach powiedzieć, tylko nie to, że są nijakie ${ }^{6}$.

Film Sara opowiada o losach byłego żołnierza wojsk specjalnych, Leona, który po powrocie z zagranicznej misji traci żonę i dzieci ${ }^{7}$, na skutek czego protagonista popada w alkoholizm. Po jakimś czasie znajduje pracę jako bodyguard, który ma chronić Sarę, córkę lokalnego gangstera, Józefa. Leon i Sara zakochują się w sobie. Józef wydaje wyrok śmierci na Leona.

Konstrukcja fabularna filmu jest schematyczna i nawiąuje w swojej poetyce do gatunku kina gangsterskiego ${ }^{8}$. Motywacje działań bohaterów sa różne, jednak w pewnym sensie zachowują tożsamość postaci typowych dla tego gatunku filmowego. Leon, wrażliwy twardziel, zostaje ochroniarzem

${ }^{6}$ Por. Jeszcze nie raz was zaskoczę..., s. 15. Ważny w niniejszym artykule jest horyzont odbioru filmu świadczący o jego interpretacyjnym potencjale.

${ }^{7}$ Nie jest jasne, czy jedna z córek Leona celuje z pistoletu do swej siostry i ją zabija (pierwsze sceny z filmu), czy też jest tak, że zabija z tej broni psa (taką wersję wydarzeń Leon przedstawia Sarze). Protagonista zaznajamia Sare z tą drugą historia, być może tak chce pamiętać przeszłość, a jednocześnie pragnie oszukać swą kochankę. Jeśli jednak widz ma uwierzyć w tę opowieść, to film traci swoją spójność i konsekwencję w budowaniu odpowiedniej dramaturgii, na co zwracała uwagę Bożena Janicka w recenzji, dz. cyt.

${ }^{8}$ Por. A. Helman, Film gangsterski, Warszawa 1990, s. 11. 
w grupie przestępczej, bo potrzebuje pieniędzy, broni ukochanej, mści się za śmierć ojca, jest szlachetny, uczciwy. Sara szuka tzw. prawdziwej miłości. Bohaterka filmu ma szesnaście lat, jej wyobrażenia o idealnym mężczyźnie są pełne klisz kulturowych i językowych modelujących w jej wyobrażeniach „koniunkcje” herosa (wykreowanego w kulturze popularnej) i romantycznego kochanka (rozumianego w sensie potocznym). Uczucie Leona i Sary przedstawione jest $\mathrm{w}$ konwencji melodramatycznej pełniącej do pewnego stopnia funkcje katarktyczne w świecie zdominowanym przez przestępców, nieuczciwych biznesmenów czy skorumpowane służby mundurowe, a więc figury agresywnej odmiany transformacji ustrojowej w Polsce.

Józef jest przestępca, który planuje zostać „uczciwym” biznesmenem i prowadzić legalne interesy (mówi o sobie, że „chce być bardziej legalny, niż prezydent Kwaśniewski” - 54 min 30 s filmu). Sara, tak zakłada jej ojciec, ma więc ukończyć studia prawnicze w USA, aby w przyszłości wraz z nim prowadzić interesy, ale już zgodnie z prawem ${ }^{9}$. Michał Piepiórka, pisząc o kinie bandyckim, do którego w różnych opracowaniach naukowych zalicza się również Sarę, zauważył, że „filmy z nurtu bandyckiego po Psach eksploatowały dialektykę fasady i kulis". Piepiórka pisał o tak pojmowanej dialektyce w odniesieniu do różnicy między obrazem polityki, który można było oglądać w telewizji, a jej kulisami. W filmie Sara mowa jest o dialektyce fasady i kulis w odniesieniu do biznesu po przełomie roku 1989. Fasada są działania biznesowe Józefa, fasadą sa jego plany dotyczące przyszłości Sary, która miałaby prowadzić uczciwy biznes zbudowany na nieuczciwych interesach ojca. W Sarze pokazane sa kulisy rozwoju biznesu w Polsce: okazuje się, że biznesmenami są byli przestępcy lub osoby z nimi powiązane ${ }^{10}$.

W poniższych rozważaniach skoncentruję się na rzeczowych i semiotycznych funkcjach książek w filmie Macieja Ślesickiego. Literatura jest watkiem pobocznym w tym filmie, jednak jej przywołanie w dialogach postaci czy w ekspozycji tła jest ważne, gdyż powoduje zacieranie granic między fikcją i rzeczywistością. W dziele Ślesickiego bohaterowie rozmawiaja o czytaniu książek, traktując je instrumentalnie, głównie są one dla nich „opałem”, ewentualnie „lekturą szkolną”. Książki w filmie Sara są przede wszystkim milczącymi świadkami dawnego życia protagonisty, nawet jeśli wśród tych książek pojawia się egzemplarz powieści Zbrodnia i kara Fiodora Dostojewskiego (43 min $35 \mathrm{~s}$ filmu).

${ }^{9}$ M. Piepiórka, Polskie kino i transformacja gospodarcza. Frustracja, krytyka i nadzieja, [w:] Kino, postkomunizm, polityka. Film w krajach Europy Środkowo-Wschodniej wobec procesów transformacji politycznej i konsekwencji roku 1989, red. M. Brzezińska-Pająk, Kraków 2018, s. 80.

10 Tamże. 
Dzieło rosyjskiego pisarza jako jedyny utwór literacki jest w filmie pokazane w zbliżeniu wypełniającym cały kadr. Powieść Dostojewskiego przestaje być w ten sposób „anonimowym” egzemplarzem, a zaczyna funkcjonować jako przedmiot diegetyczny, stając się synekdochą literatury pięknej i wrażliwości protagonisty. Ekspozycja Zbrodni i kary w oddzielnym kadrze służy charakterystyce głównego bohatera, który dawniej, jak się można domyślać, egzystował w horyzoncie poznawczym i moralnym wyznaczanym m.in. przez kanon kultury wysokiej. Barbara Janicka sceptycznie odniosła się do wykorzystania powieści Fiodora Dostojewskiego w filmie Sara, podkreślając nieprzystawalność porządków kulturowych reprezentowanych przez dzieło filmowe i utwór literacki: „Nie warto się zresztą przyczepiać do drobiazgów; w końcu Sara nie jest artykułem trwałego użytku, kaseta z tym filmem nie stanie na półce obok Zbrodni i kary"11. Oczywiście, kultura popularna ma duży potencjał mimetyczny. Wykorzystanie dzieła zaliczanego do kanonu kultury europejskiej w filmie komercyjnym miało zapewne zatrzeć granice między tzw. kulturą wysoką i popularna, ale wciąż jednak uruchamiało porządki semiotyczne będące źródłem licznych asocjacji i konotacji.

Literatura piękna w tym filmie zostaje zastapiona m.in. przez literaturę użytkowa profilująca czytelnika jako docelowego konsumenta. Sara, rozmawiając z Leonem, wspomina, że czyta książkę o orgazmie, będąca poradnikiem dla samotnej kobiety. Można ten epizod potraktować jako obraz zmian w powszechnym myśleniu o funkcjach literatury w Polsce. Sara symbolizuje pierwsze pokolenie po 1989 roku, które zaczyna myśleć według wzorców konsumenckich, globalnych ${ }^{12}$. Jej postawa obrazuje atrofię kultury czytelniczej. To właśnie w latach dziewięćdziesiątych XX wieku pojawiło się około 150 magazynów kulturalnych, jak podają Przemysław Czapliński i Piotr Śliwiński, ale tylko jeden z nich, tj. „Nowa Fantastyka”, przekroczył nakład 50 tys. egzemplarzy. Dla porównania warto wspomnieć, że pisma takie, jak „Twój Styl”, „Elle” czy „Cosmopolitan”, jeśli chodzi o liczbę wydanych egzemplarzy, były poza zasięgiem wydawniczym czasopism o charakterze kulturalno-społecznym ${ }^{13}$. Przemiany w myśleniu o literaturze i czytelnictwie były nieuchronne z powodu oddziaływania tzw. wolnego rynku oraz wpływu mediów komunikacji masowej, w tym „pism kolorowych”, plotkarskich. W bieżących analizach czytelnictwa nie uwzględnia się jednak oddziaływania filmów adresowanych do masowego odbiorcy na kulturę literacka, które przecież utrwalały stereotypowe

\footnotetext{
${ }^{11}$ Por. B. Janicka, dz. cyt.

${ }^{12}$ F. Jameson, Postmodernizm i społeczeństwo konsumpcyjne, tłum. P. Czapliński, [w:] Postmodernizm. Antologia przekładów, red. R. Nycz, Kraków 1997, s. 190-214.

${ }^{13}$ P. Czapliński, P. Śliwiński, Literatura polska 1976-1998. Przewodnik po prozie i poezji, Kraków 1999, s. 218.
} 
wyobrażenia na jej temat. Kino nurtu bandyckiego ${ }^{14} \mathrm{w}$ tym kontekście nie powoduje atrofii kultury literackiej, lecz obrazuje jej potencjalne przyczyny i skutki ${ }^{15}$. Ważne jest jednak, że_książki, stając się przedmiotami diegetycznymi w dziele Ślesickiego, zaczynają pełnić złożone semiotycznie i rzeczowo funkcje.

Warto spojrzeć na film Sara, uwzględniając perspektywę socjosemiotyczna, w której nad namysłem formalnym przeważa refleksja oparta na opisie, analizie i interpretacji tworzonych, przekazywanych i przetwarzanych znaczeń zależnych od społecznego kontekstu ${ }^{16}$. Książki jako rzeczy w filmie Sara traktuję jednocześnie jako elementy funkcjonujące w ramach praktyk społecznego tworzenia znaczeń (social meaning making practices) ${ }^{17}$, a więc to, co się dzieje między postaciami poprzez literaturę - odzwierciedla istotne przewartościowania w kulturze współczesnej.

Świat przedstawiony w filmie jest wewnętrznie spójny, a jednocześnie zewnętrznie koherentny, gdyż umożliwia udział tego, co rzeczywiste w tym, co przedstawione, dlatego oglądając film Sara - traktujemy go jako poznawczą metaforę współczesności, utrwalając wyobrażenia społeczne na temat codzienności w drugiej połowie XX wieku w Polsce. Obrazem zewnętrznie koherentnym nazywam, mając na uwadze refleksję socjosemiotyczna, film, który przekształca widza w świadka zdarzeń dziejących się w świecie przedstawionym, wzmacniając $\mathrm{w}$ ten sposób efekt uwierzytelnienia ${ }^{18}$, urealnienia przedstawionej sytuacji. Dzieje się to na poziomie języka, zdarzeń, przedmiotów, w tym książek. Film ten jest fikcja, która w pewnym sensie uznana może być za prawdę, dlatego uwierzytelnienie (ang. make-believe) rzeczywistości konstruowane jest poprzez działanie elementów o podwójnej tożsamości: semiotycznej i rzeczowej ${ }^{19}$.

${ }^{14}$ Por. M. Przylipiak, J. Szyłak, dz. cyt., s. 178-179.

${ }^{15}$ B. Janicka w recenzji filmu twierdzi, że obraz ten jest tak zrobiony, by okazał się sukcesem finansowym. Reżyserzy, szukając nowych rozwiązań stylistycznych i technicznych, starali się tworzyć dochodowe kino. W takiej postawie na pewno odwzorowane były zmiany w myśleniu o sztuce i o roli artysty, który tworzy dzieła z komercyjnych powodów. Por. B. Janicka, dz. cyt., s. 40.

${ }^{16}$ P.J. Thibault, Social Semiotics as Praxis. Text, Social Meaning Making, and Nabokov's Ada, Minneapolis 1991, s. 119.

${ }^{17}$ P.J. Thibault, dz. cyt., s. 5; Th. van Leeuwen, Introducing Social Semiotics, London and New York 2005, s. 10 i n.; P. Klos-Czerwińska, Discourse: an Introduction to van Dijk, Foucault and Bourdieu, Wrocław 2015, s. 31-41.

${ }^{18}$ F. Zippel, Fiction across Media: Toward a Transmedial Concept of Fictionality, [w:] Storyworlds across Media. Toward a Media-Conscious Narratology, ed. by M.-L. Ryan, J.-N. Thon, Nebraska Press 2014, s. 106-107.

${ }^{19}$ Por. uwagi Anny Miller-Klejsy na temat relacji między historią a kinem, [w:] A.M. Klejsa, Dekada ołowiu na ekranie. Polityczny terroryzm lat 70. we wtoskim filmie fabularnym, Łódź 2016, s. 12. 
Film „Sara” w reżyserii Macieja Ślesickiego jest dziełem intertekstualnym ze względu na liczne odniesienia do literatury oraz do kina światowego. Bohaterowie filmu zachowują się jak gangsterzy z Ojca chrzestnego (reż. F.F. Copolla, 1972) ${ }^{20}$, relacja między głównymi postaciami - dojrzałym mężczyzną (Leonem) oraz nastolatką (Sara) może być dekodowana interpretacyjnie między innymi w odniesieniu do powieści Lolita Nabokova (1955) ${ }^{21}$ czy filmu Leon zawodowiec (reż. L. Besson, 1994)22. Reżyser Maciej Ślesicki stara się pokazać polskiemu widzowi film zawierający różne klisze filmowe, jakby chciał powiedzieć, że kino polskie jest już gotowe na zmiany gatunkowe, stylistyczne, narracyjne, technologiczne, a przy tym obraz ten wciąż zachowuje swoją tożsamość, gdyż odnosi się do polskich realiów. Intertekstualność pełni różne funkcje komunikacyjne: polscy gangsterzy pokazani jako naśladowcy amerykańskich „wzorów” - czy to w filmie Sara, czy w filmie Chtopaki nie płaczq - staja się pastiszem samych siebie, czyli ludzi bez właściwości, którzy mają potrzebę opowiedzenia siebie przy wykorzystaniu mitu funkcjonującego w kulturze popularnej. Różni bohaterowie „naśladują" wzorce zachowań zapożyczone z kultury popularnej, głównie amerykańskiej23.

Polskie kino lat dziewięćdziesiątych XX wieku, podobnie jak literatura tego okresu ${ }^{24}$, jest „papierem lakmusowym” transformacji społecznych. Widz, podobnie jak czytelnik, śledzi bohaterów, którzy próbują się odnaleźć

${ }^{20} \mathrm{Na}$ co zwraca uwagę m.in. W. Kot.

${ }^{21}$ V. Nabokov, Lolita: powieść, tłum. R. Stiller, Warszawa 1991.

${ }^{22} \mathrm{Na}$ co zwraca uwagę m.in. B. Janicka.

${ }^{23}$ Zdzisław Pietrasik, omawiając trzy pierwsze spośród dziesięciu najpopularniejszych polskich filmów w latach 1991-1997, czyli Psy 2 (reż. W. Pasikowski, publiczność: 684881 widzów), Młode wilki (reż. J. Żamojda, publiczność: 541420 widzów), Nocne graffiti (reż. M. Dutkiewicz, publiczność: 500000 widzów), pisał: „Co łączy trzy tytuły zajmujące czołowe lokaty na liście najpopularniejszych filmów ostatnich lat? Pod względem formy są to filmy sensacyjno-obyczajowe, korzystające bez żenady ze sprawdzonych wzorców amerykańskiej sztuki kina popularnego. Wyrazisty bohater, szybkie tempo akcji, zwarte dynamiczne dialogi zupełnie różne od teatralnych tyrad, jakie uwielbiało nasze przegadane kino. Widać, że scenarzyści czytali dokładnie popularne amerykańskie podręczniki, gdzie się szczegółowo instruuje, jak powinien być przedstawiony bohater, w której minucie filmu ma nastapić pierwszy zwrot akcji, a w której drugi itp. [...] Mamy zatem zamiast dzieł oryginalnych - filmy na licencji obcej, tak jak pasty do zębów, kolorowe magazyny dla kobiet czy samochody składane w Polsce z importowanych segmentów. [...] O przyszłość «amerykańskiego kina polskiego» raczej nie trzeba się martwić. Czy znajdą się natomiast następcy Krzysztofa Kieślowskiego?” Na czwartym miejscu wśród najpopularniejszych polskich filmów w latach 1991-1997 był Tato w reż. M. Ślesickiego, obraz ten obejrzało 447288 widzów. Por. Z. Pietrasik, Broń się, „Polityka" 1997 , nr 15, s. 72-73.

${ }^{24}$ Szczególnym przykładem takiego zjawiska, pośród licznych dzieł literackich, jest powieść Andrzeja Stasiuka zatytułowana Dziewięć z 1999 roku. Por. omówienie: P. Czapliński, Zagtada centrum (Dziewięć A. Stasiuka), [w:] Ruchome marginesy. Szkice o literaturze lat 90., Kraków 2002. 
w nowym świecie, w którym jeszcze nie dopełniła się nowoczesność, a już ponowoczesność zaczęła się stawać porządkiem odniesienia w sensie moralnym, estetycznym i poznawczym. Chuligan (por. postaci z filmu Miasto prywatne w reż. J. Skalskiego z 1994 roku), były funkcjonariusz służb bezpieczeństwa, a szerzej mundurowych (por. Psy, reż. W. Pasikowskiego, 1992, oraz Psy 2, reż. W. Pasikowskiego, 1994, Reich, reż. W. Pasikowskiego, 2001), „cwaniaczek” (Por. Kiler, reż. J. Machulski, 1997) budują swoje fortuny, mity, opowieści, korzystając z chaosu ekonomicznego, politycznego, prawnego. W latach dziewięćdziesiątych XX wieku w kinie polskim stają się oni graczami na wolnym rynku, biznesmenami, politykami, ochroniarzami. Nie zaobserwowałem w polskim kinie lat dziewięćdziesiątych XX wieku i z początku XXI wieku sytuacji, żeby bohater (mafioso, cwaniaczek, chuligan) chciał stać się intelektualista, najczęściej zostaje biznesmenem lub politykiem. Tylko w przypadku filmu w reż. Olafa Lubaszenki z 2002 roku $E=m c^{2}$ byłemu gangsterowi, Andrzejowi Nowickiemu „Ramzesowi”, wydaje się, że może zostać intelektualista, tak jak się kupuje produkt, gadżet. Może nawet „Ramzes” nie tyle chce zostać intelektualista, co raczej chce mieć doktorat. Film ten można więc potraktować jako dzieło, w którym konfrontuja się dwa paradygmaty kultury: literacki i konsumencki.

\section{Funkcje}

W filmie Sara naśladuje się nowoczesność (rozumianą potocznie) w filmach poprzez „używanie” przedmiotów, które konotują „Zachód” (jako figury luksusu, sukcesu, transformacji elit, władzy). Przedmioty te pełnia zazwyczaj podwójną funkcję - rzeczową i semiotyczną. Funkcja rzeczowa oznacza np. w przypadku cygara palonego przez Józefa, że dana rzecz jest wykorzystywana w filmie w taki sam sposób, jak to się dzieje w realnym świecie. Natomiast funkcja semiotyczna uruchamia dodatkowe znaczenia, nadbudowane nad funkcją rzeczowa. Cygaro pełni funkcję semiotyczna, „amerykanizując” polskiego, „prawdziwego” mafioso. Palone przez Józefa cygaro pełni przy tym funkcje mityczne, gdyż uczy przeciętnego odbiorcę, jak ma myśleć o mafii w Polsce, „uczy” przestępcę, jak ma się zachowywać na „Światowym poziomie”25. Przyznać trzeba, że w latach dziewięćdziesiątych

${ }^{25} \mathrm{~W}$ pamiętnym eseju Rolanda Barthes'a, zatytułowanym Rzymianie w filmie, czytamy: „W Juliuszu Cezarze Mankiewicza wszystkie postaci maja grzywki”. Francuski semiolog pisze, że te „natarczywe grzywki” muszą w filmie manifestować rzymskość. Barthes pisze: „Ułożony na czole kosmyk daje pewność i nikt nie może wątpić, że oto znajduje się w starożytnym Rzymie”. Cygaro w filmie Sara jest znakiem o podobnym potencjale znaczeniowym, otóż uwiarygadnia ono polskiego gangstera jako gangstera o formacie zachodnim, unowocześnia 
XX wieku zdecydowana większość Polaków poznawała świat przestępczy, śledząc przekazy transmitowane przez media komunikacji masowej ${ }^{26}$ oraz oglądając obrazy filmowe w kinie, co zresztą do dziś ma swoje konsekwencje społeczne ${ }^{27}$. Polski przestępca chce być więc taki, jak przestępca pokazany w amerykańskich filmach (Chtopaki nie płacza, Sara), polski biznesmen chce być kimśs, kto będzie wyglądał tak, jak wygląda biznesmen z filmów amerykańskich (Chtopaki nie płacza, $E=m c^{2}$, Młode wilki, serial Ekstradycja). Nowoczesność, której się „uczono” na różnych poziomach, zapośredniczona w kulturze popularnej, oparta była na kopiowaniu wzorców, dlatego jej przejawy można było dostrzegać niemal w każdej formie standaryzacji dyskursu: artystycznego, politycznego, medialnego czy kulturowego. Re-

go, amerykanizuje; jakby szef polskiej mafii miał być „prawdziwym” szefem nie z powodu krwi na rękach, ale właśnie palonego cygara. „Cygaro uwiarygadnia”, jednak jest to uwiarygodnienie zapośredniczone w kulturze popularnej mającej ogromny potencjał mitotwórczy, artykułuje się w ten sposób wyobrażenie społeczne traktowane jako zsemiotyzowany ekwiwalent faktów. Por. R. Barthes, Rzymianie w filmie, [w:] tegoż, Mitologie, tłum. A. Dziadek, Warszawa 2008, s. 47.

${ }^{26}$ Wpływ mediów komunikacji masowej był więc rzeczywisty, co widać na podstawie wyników badań przeprowadzonych przez CBOS np. na temat społecznego postrzegania korupcji. Można nawet przyjaćc, że w systemie społecznym trudno było oddzielić fakty medialne od rzeczywistych, dlatego kultura popularna „kolonizowała” znaczeniowo te dziedziny, które domagały się dopowiedzenia, aby przeciętny odbiorca mógł znaleźć odpowiedzi na nurtujace go pytania. Gdy zapoznajemy się z wynikami badań przeprowadzonych w 1997 roku przez CBOS na temat korupcji, to zobaczymy, że aż $47 \%$ ankietowanych było przekonanych, że skorumpowane są urzędy i administracja, 27\% ankietowanych uważało, że skorumpowane są najwyższe władze państwowe (Sejm, rząd, ministerstwa), 25\% ankietowanych twierdziło, że skorumpowany jest wymiar sprawiedliwości (sądy, prokuratura), a 19\% ankietowanych, że policja. W przypadku wymiaru sprawiedliwości i policji obraz społeczny polepszył się w porównaniu z wynikami z 1994 roku, kiedy to odpowiednio $41 \%$ i $39 \%$ ankietowanych twierdziło, że te instytucje są najbardziej skorumpowane. Por. O społecznym postrzeganiu korupcji. Komunikat z badań, BS/72/72/97, s. 4, <https://www.cbos.pl/SPISKOM.POL/1997/K_072_97.PDF> [dostęp: 14.08.2019].

${ }^{27}$ Wpływ kultury popularnej na zbiorowe wyobrażenia o mechanizmach rządzących światem, w tym Polska, jest przedmiotem licznych studiów. Por. m.in. M. Napiórkowski, Władza wyobraźni. Kto wymyśla, co zdarzyło się wczoraj?, Warszawa 2014, s. 86-116. Gdy uwzględnia się wyniki badań na temat zaufania społecznego, w których tylko $22 \%$ ankietowanych w Polsce uważa, że należy ufać innym, a 76\% twierdzi, że należy zachować daleko posuniętą ostrożność w relacjach z innymi (są nimi m.in. politycy, urzędnicy publiczni, pracownicy mediów), ograniczając swoje zaufanie (ten trend utrzymuje się w Polsce mniej więcej na tym samym poziomie od 2002 roku), to należy postawić pytanie o przyczyny takiego stanu rzeczy. Uważam, że wśród licznych przyczyn jest wciąż funkcjonujące od lat dziewięćdziesiątych XX wieku przekonanie, że ci, którzy chcą rządzić, powiązani się z ludźmi, którzy tworza jakieś specjalne, tajne, zamknięte układy. Polskie kino od lat dziewięćdziesiątych tworzyło poznawczą ramę modelująca wyobrażenia, umożliwiając opinii publicznej funkcjonowanie i myślenie w arbitralnie przyjmowanych zależnościach przyczynowo-skutkowych. Por. Komunikat z badań: O nieufności i zaufaniu, nr 35/2018, oprac. A. Cybulska, A. Pankowski, $<$ https://www.cbos.pl/SPISKOM.POL/2018/K_035_18.PDF> [dostęp: 14.08.2019]. 
żyser Sary również szukał inspiracji w amerykańskim kinie, aby polskie kino mogło się stać kinem, w którym dobrze się opowiada kamera, dbając o porządne rzemiosło reżyserskie ${ }^{28}$.

Wśród palonych przez Leona dzieł jest egzemplarz Zbrodni i kary Fiodora Dostojewskiego. Oddzielny kadr przedstawia tylko tę książkę, aby widz mógł dokładnie ujrzeć jej tytuł. Kamera „alienuje” ${ }^{29}$ to dzieło, aby ujawnić jego obecność i jednocześnie nadać znaczenia, które przekształcaja rzecz w znak. Protagonista trzyma w ręku egzemplarz książki Zbrodnia $i$ kara wydanej przez Wydawnictwo Puls w 1992 roku (był to drugi tom dzieł zebranych Fiodora Dostojewskiego). Redakcja „Tygodnika Powszechnego" (nr 52 z 27 grudnia 1992 roku), ogłaszajac bilans roku w dziedzinie literatury, wyróżniła dwa wydawnictwa w kategorii wydawnictwo roku wydawnictwo PIW (za dzieła Witkacego) i Puls (za dzieła Fiodora Dostojewskiego) ${ }^{30}$. Oznacza to, że wydanie zbioru dzieł rosyjskiego pisarza zostało potraktowane jako ważne wydarzenie literackie roku, dlatego przedstawienie egzemplarza powieści wydanej w 1992 roku staje się synekdochą teraźniejszości. Widz otrzymuje podpowiedź, że to, co się dzieje w filmie - odnosi się do bieżącej sytuacji, przecież może on mieć u siebie w domu dokładnie to samo wydanie powieści. W obrazie Ślesickiego funkcjonują liczne indeksy czasowe podkreślające jego aktualność: stroje bohaterów, wydanie Zbrodni $i$ kary Dostojewskiego, podejmowane problemy społeczno-polityczne, auta, którymi jeżdżą bohaterowie, marki trunków, wystawy w galerii Zachęta itp. Postaci sa więc fikcyjne, ale problemy przedstawione w filmie sa uwierzytelnione - urealnione. Egzemplarz powieści Zbrodnia i kara, która główny bohater filmu rozrywa i wkłada do ognia, pełni więc dwie podstawowe funkcje: rzeczową i semiotyczna ${ }^{31}$.

${ }^{28}$ Jeszcze nie raz was zaskoczę..., s. 15.

${ }^{29}$ Użyte przeze mnie (w formie orzeczenia) pojęcie „alienacji” zaczerpnąłem, zainspirowany, z pracy S. Kracauera zatytułowanej Teoria filmu. Autor tej pracy pisze: „Filmy alienują nasze otoczenie przez to, że je ujawniaja. W filmach wciąż powtarza się następująca scena: dwie lub więcej osób rozmawiają ze soba, a kamera, jak gdyby rozmowa nic jej nie obchodziła, powoli panoramuje po pokoju, zapraszając nas do obojętnego obserwowania twarzy słuchaczy oraz rozmaitych mebli. Taka panorama zawsze, bez względu na znaczenie w danym kontekście, rozbija dobrze znaną całość sytuacji i konfrontuje widza z izolowanymi zjawiskami, które przedtem zlekceważył lub przeoczył jako oczywiste składniki tej sytuacji. W miarę jazdy kamery firanki stają się rozmowne, oczy opowiadają własną historię". S. Kracauer, Teoria filmu: wyzwolenie materialnej rzeczywistości, tłum. W. Wertenstein, wstęp A. Helman, Gdańsk 2008, s. 83.

${ }^{30}$ Wszystkie dane podaję za: Kalendarium życia literackiego 1976-2000. Wydarzenia, dyskusje, bilanse, red. P. Czapliński, M. Leciński, E. Szybowicz, B. Warkocki, Kraków 2003, s. 373.

${ }^{31}$ Por. uwagi na temat różnic między funkcjami rzeczowymi i semiotycznymi przedmiotów, [w:] S. Żółkiewski, Nauka o kulturze i semiotyka, „Teksty” 1973, nr 3, s. 70. 
Funkcja rzeczowa oznacza, że przedmiot, którym jest książka, jest czymś, co się czyta, choć niekiedy służy do podtrzymywania ognia - o tyle więc w realności świata przedstawionego papier jest wciąż czymś, co może płonać itp. Okładka książki (gdy widz rozpoznaje wydanie Wydawnictwa „Puls” i pamięta rok opublikowania Zbrodni i kary) pełni również funkcję rzeczową. Reżyser wzmocnił „efekt teraźniejszości”, wykorzystując najbardziej aktualne podówczas wydanie powieści, aby widz odniósł wrażenie, że jest świadkiem zdarzeń in statu nascendi. Powyższe uwagi można podsumować w formie następującej hipotezy: funkcja rzeczowa, którą pełni obiekt, powoduje przekraczanie granic między tym, co fikcyjne, i tym, co rzeczywiste.

Egzemplarz powieści Dostojewskiego pełni również funkcję semiotyczną: uzupełnia charakterystykę protagonisty, o czym była mowa, konotuje przewartościowanie $\mathrm{w}$ sferze kultury $\mathrm{w}$ okresie transformacji ustrojowej i w związku z tym metaforycznie obrazuje zanik kanonów konstytuujących centrum dyskursów kulturowych ${ }^{32}$. Półka z książkami w stosunkowo pustym mieszkaniu konotuje system wartości ważnych dla protagonisty. Na pytanie Sary, czy czyta książki, Leon odpowiada, że „pali nimi w piecu”, a więc już tylko do przeszłości należy to, kim był. Wartości, na których protagonista opiera swoje relacje z ojcem czy z Sara, wpisują się w myślenie o tym, że to, co dobre, musi być oparte na wiedzy, wszak książki w tym kontekście sa znakami konotującymi wiedzę. Protagonista, który był dobrze wykształcony, wspomina przecież w rozmowie z ojcem o profesorze z Afryki, u którego był na stypendium (78 min $33 \mathrm{~s}$ filmu), zna język chiński (68 min $40 \mathrm{~s}$ filmu), stał się ochroniarzem pracującym dla gangstera. Jego upadek jest upadkiem w sensie egzystencjalnym, którego symbolem staje się „los” książek traktowanych jako „nieme” i nieprzydatne rekwizyty. Niedoszły uczony, który stał się ochroniarzem gangstera, symbolicznie obrazuje podporządkowanie się nowemu kulturowemu centrum konstruowanemu przez kogoś, kto ma dostęp do pieniędzy i władzy. Leon, gdyby nie miłość, zapewne uległby złudzeniu, że w świecie współczesnym nie liczy się wiedza i normy moralne, liczy się władza, liczy się pieniądz, o tyle też uczucie łączące go z Sarą jest hipertekstualnym (w rozumieniu Genette'a) odniesieniem do uczucia między Raskolnikowem i Sonią, bohaterami powieści Fiodora Dostojewskiego. Sara, podobnie jak Sonia, jest źródłem miłości „soteriologicznej” - wybawiającej

${ }^{32}$ Podział na funkcję rzeczową i semiotyczna jest podziałem rozpatrywanym z perspektywy wewnętrznej filmu, a więc z perspektywy świata, w którym żyją bohaterowie i gdzie dzieje się akcja, jak i z perspektywy zewnętrznej, która jest udziałem widza. Dychotomia między funkcją rzeczową i semiotyczna powoduje „rozregulowanie” podziału na to, co realne i na to, co iluzoryczne - zarówno dla bohaterów, jak i dla widzów. Por. uwagi J. Łotmana odnoszące się do znakowej natury tekstu artystycznego. J. Łotman, Kultura i eksplozja, tłum. B. Żyłko, Warszawa 1999, s. 109-115. 
i zbawiającej upadłego człowieka. Figurą tego upadku jest „los” książek w życiu protagonisty.

Dychotomia między funkcjami rzeczową i semiotyczną powoduje, że przedmiot, tj. egzemplarz książki Zbrodnia i kara, nie tracąc swego znaczeniowego potencjału w filmie ${ }^{33}$, utrwalając efekt realności, jednocześnie uruchamia konteksty, z powodu których pojawiaja się pytania nie tylko o znak, o tekst, ale również o dyskurs. Właśnie dlatego możemy wpisywać rozważania na temat tego filmu w dyskursy dotyczące przemian społecznych i kulturowych, które wpływają na zmianę w postrzeganiu literatury. W filmie Sara książki płona, w filmie Chtopaki nie płacza a daptacja filmowa opowiadania Tomasza Manna Śmierć $w$ Wenecji potraktowana jest jako kryminał. Już chociażby te dwa przykłady filmowe potwierdzaja zmiany w definiowaniu kulturowego centrum w Polsce po 1989 roku. Rodzący się podówczas kapitalizm - wraz z akolitami transformacji (gangsterami, biznesmenami, politykami) - powoduje, że wykształcony człowiek zmuszony jest dostosować się do systemu, w którym albo literatura przestaje mieć znaczenie (Sara), albo nic już nie znaczy (Chłopaki nie płacza). Sara Ślesickiego jest filmem o konfrontacji książki z bronią (książki stają się niemymi świadkami zdarzeń, ich właściciel, Leon, inaczej niż Kien z Auto da fé Canettiego, nie słyszy ich $k r z y k u^{34}$ ), wiedzy z władzą (ten, który płaci Leonowi, ma nad nim władzę ta zależność na poziomie ekonomicznym nie determinuje jednak zależności na poziomie moralnym, wszak Leon, który czytał Zbrodnię $i$ karę, buntuje się przeciw swemu pracodawcy), tego, co było (nawet jeśli jest idealizowane), z tym, co właśnie następuje (Leon jako figura społeczeństwa myślącego tradycyjnie, Sara jako figura nowego pokolenia usposobionego konsumencko - w obydwu przypadkach sa to ujęcia stereotypowe).

Egzemplarz Zbrodni i kary „projektuje” również profil potencjalnego odbiorcy filmu, gdyż musi nim lub nią być ktoś, kto zna tę powieść, kto wie, jakie ma ona znaczenie w kulturze europejskiej, w tym polskiej. Projektowanie odbiorcy opiera się na zawiązaniu z nim paktu czytelniczego: żeby zrozumieć, co się dzieje z głównym bohaterem spalającym powieść Dostojewskiego, trzeba tę powieść znać. Innym przykładem na zawiązanie podobnego paktu jest przywołana wcześniej scena z filmu Chłopaki nie płaczq - żeby zrozumieć komizm sytuacji przedstawionej w filmie, w której gangsterzy oglądają film Śmierć $w$ Wenecji, należy wiedzieć, że słowo

${ }^{33}$ Już w latach sześćdziesiątych XX wieku Jurij Łotman pisał, że problem znaczeń to problem kluczowy dla wszystkich nauk spokrewnionych z semiotyka. Por. J. Łotman, $O z n a-$ czeniach we wtórnych systemach modelujacych, tłum. J. Faryno, „Pamiętnik Literacki” 1969, z. 1 , s. 279 .

${ }^{34}$ „Wtedy usłyszał dzikie wołania: były to krzyczące książki”. E. Canetti, Auto da fé, tłum. E. Sicińska, Warszawa 2007, s. 758. 
„śmierć" z tytułu zacytowanego filmu nie odnosi się do żadnego kryminału, a postać siedząca w gondoli to Aschenbach - główny bohater filmu Viscontiego, a nie jakiś gangster.

Zależności między funkcjami semiotycznymi i rzeczowymi modeluja działanie szeregu znaczeniowego służącego do przekraczania granicy oddzielającej umowność świata przedstawionego od rzeczywistości. Szereg znaczeniowy nie podważa natury „realności” świata wewnętrznego filmu bohaterowie wciąż żyją według ontologii rzeczywistości będącej podstawa każdej akcji filmowej: bohater zastrzelony - ginie, podpalony budynek płonie itd., służy zaś zatarciu różnic między tak pojmowanym światem wewnętrznym, podporządkowanym postaciom i akcji, a światem zewnętrznym, „skolonizowanym” przez widza. Zacieranie tego typu różnic podkreśla ideologiczny potencjał dzieła filmowego. Przy takim założeniu film przestaje być jedynie obrazem autotelicznym, bowiem w interakcji z widzem staje się „kliszą" codzienności, którą można odpowiednio ustawić „pod słońce”, aby obraz stał się przezroczysty, umożliwiając odbiorcy interpretacje o charakterze politycznym, społecznym czy kulturowym.

Poniżej skoncentruję się na relacjach w szeregu znaczeniowym charakteryzującym głównego bohatera i książki.

\section{Bohater i książki}

Interakcje protagonisty z książkami, w tym z egzemplarzem Zbrodni $i$ kary, opierają się na analogii między narracją o bohaterze i narracja o przedmiocie, przy czym obydwa porządki narracyjne sa komplementarne względem siebie. Opowieści o protagoniście $(\mathrm{P})$ oraz o książkach $(\mathrm{K})$ mają podobną konstrukcję. Można to wykazać, korzystając z uniwersalnego modelu narracyjnego: exposition (1), complication (2), climax (3), denouement (4) ${ }^{35}$ :

P1: pijany żołnierz (synekdocha postawy), życie rodzinne (synekdocha sytuacji), rozpad dotychczasowego życia;

K1:półka z książkami (mieszkanie jest niemal puste, zaniedbane, więc tym

bardziej semiotycznych cech nabiera wyeksponowany na scenie obiekt), pytanie Sary dotyczące lektur ważnych dla protagonisty;

${ }^{35}$ Analogia między opowieścią o protagoniście i opowieścią o książkach powstała na podstawie inspiracji zaczerpniętych z rozważań Paula J. Thibaulta, który - w nawiązaniu do Hymesa - przeprowadził intertekstualna analizę Lolity i Ady (ang. Ada or Ardor: A Family Chronicle) Nabokova. Por. P.J. Thibault, dz. cyt., s. 142. Celowo nie tłumaczę terminologii na język polski, aby zaznaczyć, że traktuję ten model jako uniwersalny, choć uwarunkowany socjosemiotycznie. 
P2: inwersja funkcji - nowa życiowa rola protagonisty (ochroniarz gangstera);

K2:inwersja funkcji - przedmiot do czytania staje się przedmiotem do spalenia;

P3: romans między Leonem i Sara, konflikt z gangiem;

K3:palenie egzemplarza Zbrodni i kary (przewartościowanie jako punkt zwrotny w życiu protagonisty);

P4: protagonista akceptuje własną tożsamość (w rozmowie z ojcem wspomina profesora z Afryki, którego odwiedził w ramach stypendium (78 min $8 \mathrm{~s}$ filmu), odchodzi w nieznane wraz z Sara, pokonawszy wcześniej zło;

K4:akceptacja tożsamości protagonisty powiązana z losem książek w jego życiu; książki „ustępują” konsumeryzmowi, „znikają” (konsumpcja definiuje nowe kulturowe centrum, w którym znajdują się nabywane drogie rzeczy, książki - jeśli już funkcjonują, to na peryferiach; $48 \mathrm{~min} 3 \mathrm{~s}$ filmu).

Analogie od P1:K1 do P4:K4 obrazują wzmocnienie relacji między losem protagonisty i losem książek. Implikacje P1-P2-P3-P4 oraz K1-K2K3-K4 mają figuratywny charakter. Losy głównego bohatera są synekdochą losów osób, które muszą się odnaleźć w rzeczywistości, w której obowiązują nowe reguły, w rzeczywistości, w której tradycja (symbolami jej są m.in. książki) jest brana w obyczajowy nawias przez rozwijający się kapitalizm. $\mathrm{W}$ tym kontekście to, co przeszłe, ustępuje temu, co dzieje się tu i teraz ${ }^{36}$ : Sara jako szesnastolatka szuka kochanka, natomiast ojciec protagonisty, gdy był w jej wieku, to spalił niemiecki czołg (Leon wspomina to wydarzenie, por. $76 \mathrm{~min} 46 \mathrm{~s}$ filmu). Różne pokolenia, a więc odmienne doświadczenia, oznaczają zmianę paradygmatu tożsamościowego, w który wpisany jest „zanik poczucia historii”. Doświadczenia Sary i ojca protagonisty z powodów historycznych są idiomatyczne, nieprzekładalne i nieporównywalne. Nastawienie bohaterów do książek odzwierciedla to, co w innym kontekście wyjaśniał Fredric Jameson, pisząc, że „współczesny system społeczny zaczął stopniowo tracić zdolność przechowywania przeszłości, żyjąc w wiecznej teraźniejszości”"

Sara, a także jej koleżanki i koledzy są figurami pokolenia, które dojrzewa już po 1989 roku - ważne dla nich jest NBA, chca konsumować, zażywać narkotyki (pod szkołą pojawia się dealer narkotykowy), sa zapatrzeni w (stereotypowo przedstawiany) Zachód, choć nie przestają marzyć o miłości. Postawa Leona jest potoczną wersją romantycznego bohatera: jest wrażli-

\footnotetext{
${ }^{36}$ F. Jameson, dz. cyt., s. 212-213.

37 Tamże, s. 212.
} 
wy, mówi o miłości: „miłość to takie coś, czego nie ma” (44 min 30 s filmu), broni swej ukochanej, dosłownie osłaniając ją ciałem, walczy ze złem i jest niepokonany w tej walce.

W przypadku semiotycznej relacji między porządkami P2 oraz K2, którą nazywam inwersją funkcji, widzimy, w jaki sposób zobrazowane zostało przejście od paradygmatu tradycyjnego - odniesień do tego wzorca można znaleźć wiele, m.in.: pochodzenie protagonisty, jego wykształcenie, znajomość literatury, etos oparty na takich wartościach, jak honor czy poświęcenie (dla ukochanej, dla ojca) - do globalnego (w którym dominować musi młodość, konsumpcja, tymczasowość oraz przygodność). W tym kontekście szczególnego znaczenia nabierają wcześniej zacytowane słowa Fredrica Jamesona mówiące o tym, że współczesny system społeczny zaczą tracić stopniowo zdolność do przechowywania przeszłości, wszak książki również służą między innymi do przechowywania przeszłości. Przejście od paradygmatu tradycyjnego do globalnego jest jedną z przyczyn atrofii kultury literackiej.

\section{Zakończenie}

Film Sara jest obrazem przemian, które następowały w sferze kulturowej, społecznej i politycznej w społeczeństwie polskim w latach dziewięćdziesiątych XX wieku. Filmowe przedstawienia książek pełnią różne funkcje - w zależności od gatunku i stylu. Trudno jednak pojać obecna sytuację w polskiej kulturze bez zrozumienia tego, czym były książki w kinie w tamtym okresie, jakie funkcje rzeczowe i semiotyczne pełniły podówczas. Wiele jest opracowań w polskim piśmiennictwie filmoznawczym odnoszącym się do tego okresu. Brakuje natomiast odniesień do literatury i książek traktowanych jako medium przemian, które z jednej strony miały charakter reaktywny (reakcja na współczesność), a z drugiej - kreatywny (nowe cele, nowe poetyki). Lata dziewięćdziesiąte XX wieku były okresem przełomów w Polsce - ekonomicznych, politycznych, kulturowych i społecznych. Ksiażki w tym okresie miały swoje rozmaite historie, bohaterowie kina popularnego rzadko sięgali po literaturę, wykazując się przy tym ogromna skutecznością w pozyskiwaniu nobilitujacych ich godności i funkcji. Filmowy gangster stawał się biznesmenem, który nie wahał się w narzucaniu swojemu otoczeniu określonych zachowań i norm, relatywizując porządki etyczne, tworzac nowe centra kulturowe i spychajac dotychczasowe na peryferia. Liczyła się skuteczność w działaniu, a nie umiejętność mówienia o nim. Atrofia kultury literackiej była więc konsekwencją przemian społeczno-kulturowych, których metaforami poznawczymi były między innymi filmy, takie jak Sara. 


\section{BIBLIOGRAFIA}

\section{OPRACOWANIA}

Adamczak M., Globalne Hollywood, filmowa Europa i polskie kino po 1989 roku. Przeobrażenia kultury audiowizualnej przełomu stuleci, Gdańsk 2010.

Barthes R., Rzymianie w filmie, [w:] tegoż, Mitologie, tłum. A. Dziadek, Warszawa 2008. Canetti E., Auto da fé, tłum. E. Sicińska, Warszawa 2007.

Czapliński P., Zagłada centrum (Dziewięć A. Stasiuka), [w:] Ruchome marginesy. Szkice o literaturze lat 90., Kraków 2002.

Czapliński P., Śliwiński P., Literatura polska 1976-1998. Przewodnik po prozie i poezji, Kraków 1999.

Dostojewski F., Zbrodnia i kara, tłum. Cz. Jastrzębiec-Kozłowski, Londyn 1992.

Helman A., Film gangsterski, Warszawa 1990.

Jameson F., Postmodernizm i społeczeństwo konsumpcyjne, tłum. P. Czapliński, [w:] Postmodernizm. Antologia przekładów, red. R. Nycz, Kraków 1997, s. 190-214.

Janicka B., Tato, pa! („Sara”), „Kino” 1997, nr 7-8, s. 40-42.

Jeszcze nie raz was zaskoczę. Rozmowa z Maciejem Ślesickim, rozm. J. Gierałt, „Kino” 1997, nr 5.

Kalendarium życia literackiego 1976-2000. Wydarzenia, dyskusje, bilanse, red. P. Czapliński, M. Leciński, E. Szybowicz, B. Warkocki, Kraków 2003.

Klejsa A.M., Dekada ołowiu na ekranie. Polityczny terroryzm lat 70. we włoskim filmie fabularnym, Łódź 2016.

Klos-Czerwińska P., Discourse: an Introduction to van Dijk, Foucault and Bourdieu, Wrocław 2015.

Komunikat z badań: O nieufności i zaufaniu, nr 35/2018, oprac. A. Cybulska, A. Pankowski, $<$ https://www.cbos.pl/SPISKOM.POL/2018/K_035_18.PDF> [dostęp: 14.08.2019].

Kot W., Antybohater w potrawce. Film „Sara” w reżyserii Macieja Ślesickiego, „Wprost” 1997, nr 22.

Kracauer S., Teoria filmu: wyzwolenie materialnej rzeczywistości, tłum. W. Wertenstein, wstęp A. Helman, Gdańsk 2008.

Leeuwen Th. van, Introducing Social Semiotics, London and New York 2005.

Łotman J., Kultura i eksplozja, tłum. B. Żyłko, Warszawa 1999.

Łotman J., O znaczeniach we wtórnych systemach modelujacych, tłum. J. Faryno, „Pamiętnik Literacki” 1969, z. 1.

Nabokov V., Lolita: powieść, tłum. R. Stiller, Warszawa 1991.

Napiórkowski M., Władza wyobraźni. Kto wymyśla, co zdarzyło się wczoraj?, Warszawa 2014.

O społecznym postrzeganiu korupcji. Komunikat z badań, BS/72/72/97, <https://www. cbos.pl/SPISKOM.POL/1997/K_072_97.PDF> [dostęp: 14.08.2019].

Piepiórka M., Polskie kino i transformacja gospodarcza. Frustracja, krytyka i nadzieja, [w:] Kino, postkomunizm, polityka. Film w krajach Europy Środkowo-Wschodniej wobec procesów transformacji politycznej i konsekwencji roku 1989, red. M. Brzezińska-Pająk, Kraków 2018.

Pietrasik Z., Broń się, „Polityka” 1997, nr 15, s. 72-73. 
Pietrasik Z., O kurna, Linduś!, „Polityka” 1997, nr 23.

Przylipiak M., Szyłak J., Kino najnowsze, Kraków 1999.

„Sara”. Bajka dla dorostych, <https://film.interia.pl/wiadomosci/news-sara-bajka-dla-doroslych,nId,2396697\#comments4-1> [dostęp: 10.08.2019].

Thibault P.J., Social Semiotics as Praxis. Text, Social Meaning Making, and Nabokov's Ada, Minneapolis 1991.

Zippel F., Fiction across Media: Toward a Transmedial Concept of Fictionality, [w:] Storyworlds across Media. Toward a Media-Conscious Narratology, ed. by M.-L. Ryan, J.-N. Thon, Nebraska Press 2014.

Żółkiewski S., Nauka o kulturze i semiotyka, „Teksty” 1973, nr 3.

\section{FILMOGRAFIA}

Chtopaki nie płacza, reż. O. Lubaszenko, 2000.

$E=m c^{2}$, reż. O. Lubaszenko, 2002.

Ekstradycja (serial), reż. W. Wójcik (seria pierwsza z 1995 roku, następnie: 1996 i 1998).

Kiler, reż. J. Machulski, 1997.

Leon zawodowiec, reż. L. Besson, 1994.

Miasto prywatne, reż. J. Skalski, 1994.

Młode wilki, reż. J. Żamojda, 1995.

Nocne graffiti, reż. M. Dutkiewicz, 1996.

Ojciec chrzestny, reż. F.F. Copolla, 1972.

Poranek kojota, reż. O. Lubaszenko, 2001.

Psy, reż. W. Pasikowski, 1992.

Psy 2, reż. W. Pasikowski, 1994.

Reich, reż. W. Pasikowski, 2001.

Sara, reż. M. Ślesicki, 1997.

Śmierć w Wenecji, reż. L. Visconti, 1971.

Tato, reż. M. Ślesicki, 1995. 